\title{
Den politiske betydning af værdier og moral
}

\section{Torben Krogh}

De tre forskerbidrag til den udenrigspolitiske årbog 2005 fra Dansk Institut for Internationale Studier fremstår umiddelbart som meget forskellige, men har det til fælles, at de alle belyser den politiske betydning af begreber som værdier og moral

Per Carlsen og Hans Mouritzen (red): Danish Foreign Policy Yearbook 2005. Danish Institute for International Studies. 2005. $192 \mathrm{~s}$.

Når analysen af den store politik og dens spil om magten folder sig ud, glider begreber som værdier eller moral som regel i baggrunden. I realpolitikkens verden er det andre faktorer, der tillægges afgørende betydning. Staterne vil med forskellige midler til stadighed søge at opnå den størst mulige sikkerhed. Samtidig fremtræder $\varnothing$ konomiske interesser ofte som en åbenlys drivkraft for den udenrigspolitiske kurs.

Selv om sådanne overordnede strategiske hensyn ubetvivleligt er af central betydning, kan de imidlertid ikke stå alene i vurderingen af den moderne udenrigs- og sikkerhedspolitik. I mange tilfælde er den hårde strategiske politik vævet uløseligt sammen med værdibaserede hensyn. Sådan har det til en vis grad forholdt sig igennem mange årtier i de demokratiske samfund, hvor politiske beslutninger er underkastet offentlig indsigt og diskussion. Men efter Den Kolde Krigs ophør er udviklingen accelereret.

På samme tid har det trusselsbillede, vi skal forholde os til her i Danmark, grundlæggende ændret karakter. Op igennem 1990'erne var det den almindelige antagelse, at ydre trusler på det nærmeste helt var forsvundet. Den opfattelse er blevet revideret siden 11. september 
2001. Men den potentielle trussel, der er forbundet med terrorismen, kræver et ganske andet reaktionsmønster end tidligere tiders forsvar af den nationale sikkerhed og suverænitet.

En del af svaret har bestået i at gå i krig. Først i Afghanistan, siden i Irak. Det er en politik, som USA har udstukket, men Danmark er et af de lande, der med størst konsekvens har bakket op om denne linje. Spørgsmålet er så, om det danske samfund har været rustet til at løfte denne opgave - militært såvel som politisk.

\section{Dybtgående uenighed}

\section{Det er emnet, Mikkel Vedby}

Rasmussen belyser i sit bidrag til DIIS-årbogen for 2005, der traditionen tro udgives på engelsk. Som nøglebegreb opererer han med "danske værdier". De kom under pres, da en dansk kaptajn blev kaldt hjem fra Irak i 2004 på mistanke om at have behandlet irakiske fanger for hårdhændet. Ordet tortur florerede i medierne, selv om der end ikke i værste fald var tale om noget, der bare mindede om de overgreb, amerikanske soldater forinden var blevet afsløret i. Og det udløste en debat, der ifølge forfatterens vurdering viste en dybtgående uenighed blandt danskerne om karakteren af militære konflikter og karakteren af den danske deltagelse i dem.

I denne debat blev der argumen- teret ud fra værdinormer. På den ene side stod fortalerne for aktiv dansk deltagelse og offensive militære operationer. De slog på, at Danmark kun på denne måde kan leve op til sine forpligtelser som et globaliserende samfund. På den anden side talte mange for, at den militære indsats i Irak undergraver netop de værdier, der definerer det danske samfund. Derfor bør tropperne trækkes hjem.

Som fortalere for de to standpunkter citerer Vedby Rasmussen især Uffe Ellemann-Jensen og Herbert Pundik. Fra aktive politikere er der derimod ingen centrale citater i denne sammenhæng. Og det skyldes, at den modsætning, der her trækkes frem, ikke uden videre følger de sædvanlige skillelinjer i Folketinget, når det gælder Irak-krigen. Også fra regeringens side er der blevet ført politik ud fra forestillingen om særlige danske værdier.

Det mest markante eksempel var forsvarsminister Søren Gades hurtige hjemkaldelse af chefen for den danske base, Camp Eden, da noget kunne tyde på, at han ikke havde haft fuld kontrol over tingene. Det signal, ministeren her sendte under stor politisk opbakning, bestod i at fortælle offentligheden, at danske værdier og normer her kunne være blevet krænket. Som Vedby Rasmussen konstater, var det ikke en disposition, der højnede moralen blandt officerer og soldater ude i krigszonen. 


\section{LITTERATUR Den politiske betydning af verdier og moral}

\section{Forsvarsforliget}

Efterhånden lød der dog røster, som fremhævede det umulige i uden videre at overføre danske normer til en blodig og kompliceret guerillakrig under fremmedartede forhold. Hvis de danske politikere og den danske befolkning ikke forstår, at det forholder sig sådan, bør danske soldater ikke sætte livet på spil under disse vilkår. Nu mener disse deltagere i debatten imidlertid, at den danske tilstedeværelse er vigtig. Derfor må de henvise til et andet værdisæt end det specifikt danske. Det, de udsendte soldater kæmper for sammen med USA og andre allierede, er demokrati, fredeliggørelse og sikkerhed - med andre ord værdier, der må siges at være internationale.

Den store problem ligger imidlertid i selve den dybe uenighed. Formelt set arbejder tropperne i Irak på et bredt politisk mandat. Reelt hersker der vidt forskellige opfattelser af, hvad deres rolle egentlig er - hvis de overhovedet burde have nogen.

Som ramme om sin analyse har Vedby Rasmussen sat forsvarsforliget fra 2004. Det vil i de kommende år bane vejen for et militær, der i højere grad end i dag vil være i stand til at arbejde i konfliktområder og egentlige krigszoner. I den forstand er der tale om en videreudvikling af den struktur, der allerede blev opbygget i 1990'erne. Men ændringerne er denne gang mere vidtrækkende. De afspejler ikke mindst, at dan- ske militære indsatser nu ikke blot skal dreje sig om fredsbevaring, konfliktkontrol og beskyttelse, men også om mere offentlige, krigsprægede operationer.

Ressourcerne er imidlertid af en sådan størrelse, at de to brigader, flådeenhederne og de seks F16-fly ikke har kapacitet til at opretholde langvarige engagementer som det, der nu finder sted i Irak. Det er ikke en opgave af denne art, det danske militær er struktureret til at varetage.

Konklusionen er derfor klar, selv om Vedby Rasmussen stiller den op som en række valg. Ud fra de beslutninger, der hidtil er truffet, må det imidlertid konstateres, at Danmark hverken politisk, folkeligt eller militært har forberedt sig på at være aktiv deltager i en krig som den, der foregår i Irak.

\section{Erindrigspolitik}

Hvor "værdier" er et centralt begreb i Vedby Rasmussens artikel, spiller ordet "moral" en tilsvarende rolle i Uffe Østergårds artikel om det, han kalder erindringspolitik. Omdrejningspunktet her er de senere års stigende interesse for de folkemord og andre grusomme overgreb, der er blevet begået både under Den Anden Verdenskrig og i andre sammenhænge. En særlig betydning i den forbindelse har eftertidens forhold til jødeudryddelserne - Holocaust - men begrebet folkedrab har 
jo sørgeligt nok ikke mistet dets aktualitet.

Uffe Østergård argumenterer godt for det politisk nødvendige i den politik, der er forbundet med at udstede officielle undskyldning for fortidens forbrydelser. Det bidrager til at fastholde den kollektive erindring, der er så vigtig i bestræbelserne på at undgå gentagelser.

Erindringspolitik må uundgåeligt være forbundet med moralske normer. Østergaard fremhæver i den forbindelse, at moral i høj grad er en politisk faktor. Han citerer Fridtjof Nansen for udsagnet om, at "realpolitik er moralpolitik".

Det tog dog mange år efter Anden Verdenskrig, før det internationale samfund kunne komme nogenlunde overens om at oprette en domstol til behandling af krigsforbrydelser. Den er nu i funktion, men stadig genstand for intens amerikansk modstand. Supermagten mener, at dens statsborgere kun skal kunne retsforfølges ved dens egne domstole. En række lande har efter stærkt pres givet tilsagn om, at de ikke vil udlevere mistænkte amerikanske borgere til domstolen i Haag.

\section{Et større Europa}

Denne konflikt er en blandt flere, der i de senere år har belastet forholdet mellem USA og en større gruppe europæiske lande. De atlantiske bånd er ikke så tætte, som de har været. Og det er skadeligt for de kommende års vigtigste europæiske projekt, mener Daniel Hamilton, der er direktør for the Paul Nitze School of Advanced International Studies.

Projektet består i at sikre stabilitet og demokrati i et Europa, der er betydelig bredere end selv det udvidede EU. Det er en opgaver der ikke kan løftes uden et nært transatlantisk samarbejde. For selv om medlemskab af hverken NATO eller EU står lige for døren, så må der etableres konkrete og løfterige arrangementer med lande som Ukraine, Georgien og andre, der har bevæget sig ind på reformernes og demokratiseringens vej.

Ud over nødvendigheden af et forbedret atlantisk forhold fremhæver Hamilton også den rolle, mindre lande som Danmark kan spille i en sådan proces. Ikke mindst er der rige erfaringer at hente i det samarbejde, de nordiske lande hurtigt udviklede med de tre nye uafhængige republikker i Baltikum.

I modsætning til Vedby Rasmussen og Østergård arbejder Hamilton ikke eksplicit med hverken værdiernes eller moralens betydning for de politiske relationer. Men i fremhævelsen af den indflydelse mindre lande kan få i bestræbelserne på at skabe et bredere Europa, arbejder han ikke desto mindre med disse begreber.

Årbogens fjerde artikel er den årlige oversigt fra Udenrigsministe- 


\section{LITTERATUR Den politiske betydning af verdier og moral}

riets direktør Friis Arne Petersen.

Ikke overraskende lægger han vægt på EU's udvidelse, Danmarks plads i FN's Sikkerhedsråd og betydningen af et godt forhold mellem Europa og USA. Men i øvrigt kommer han godt omkring de emner, der har høj prioritet i dansk udenrigspolitik.

En bestemt iagttagelse er i den forbindelse af særlig interesse. Efter udvidelsen har EU-landene udvist en stigende trang til at samarbejde bilateralt og i skiftende ad hoc-koali- tioner. For et mindre EU-land som Danmark betyder det, at der lægges øget vægt på "aktive og målrettede bilaterale relationer med alle EUpartnere for at fremme nationale interesser”. Direktøren konstaterer, at politik- og beslutningsskabelse nu i stigende grad sker andre steder end i de institutionelle strukturer og ved konferencebordene i Bruxelles. Det er en udvikling, det vil være værd at holde øje med. 